\title{
25. The origins of School Strike 4 Climate NZ
}

\section{Sophie Handford and Raven Maeder}

School Strike 4 Climate NZ (SS4CNZ) is a student-led, student-powered movement made up of young Aotearoa New Zealanders from every corner of the country, who are mobilizing to put pressure on their government to take immediate, transformative action on the climate crisis. These students, ranging from ages 8-22, are united by their shared concern for their futures, and their belief that achieving climate justice is and must be possible. In line with the international School Strike 4 Climate (SS4C) and Fridays For Future (FFF) movements, their overarching demand is simple: our leaders must take urgent action on the climate crisis and protect our generation, and all coming generations' right to a safe future on this planet.

The international FFF movement was sparked by the courageous actions of Greta Thunberg, a 15-year-old Swedish teenager, in August 2018. After years of anxiety, frustration and fear about her government's inaction on the climate crisis, Greta decided to stage a solo strike, and sit outside the Swedish Parliament every Friday rather than attending school. Her message to her leaders, and those around the globe, was "why should we study for this future, if no one is doing anything to protect that future?".

This message was one that resonated with young people around the world, and though Greta may not have realized it at the time, was the beginning of an international movement of millions, FFF. Soon students in over 40 countries began striking from school weekly for the climate, each with demands for their governments and elected leaders specific to their local context. Out of FFF, grew SS4C, which is rooted in Australia. Although the movements are very similar in their demands for climate action, SS4C uses the tactic of organizing less frequent strikes, with more effort to mobilize a larger portion of the population.

At the end of 2018, Sophie Handford, an 18-year-old recent high school graduate from Kāpiti, Aotearoa New Zealand, was scrolling through her Instagram when she came across photos of the first nationwide strike the Australian School Strikers had led. The messages on the placards, emotions on faces and chants of thousands of voices resonated deeply with Sophie and 
the fear she had been feeling around the future her generation would inherit if we failed to treat climate change like the crisis that it is and act, now. Only several days after this moment, an Aotearoa New Zealand branch of SS4C was born. Having recently graduated, Sophie luckily still had a network at her high school, Kāpiti College, namely their Eco Action Group, who were all extremely excited to be involved in the early stages of bringing this movement to Aotearoa New Zealand. Sophie had also been added to a Facebook group of young environmental activists from across Aotearoa New Zealand in the middle of 2018 and used this group as an avenue to reach out to more people to get the movement off the ground. Within three days, the team, mainly from Kāpiti College, had a social media presence and a website. They also had two video calls to plan for the coming weeks and months.

Throughout the early stages, Sophie was also being introduced to the international movement and was quick to find out that there was an international strike on 15 March 2019. The SS4CNZ national team at the time worked alongside scientists, older activists and other existing climate groups to develop a clear set of demands for their elected leaders. ${ }^{1}$ They also began signing up people from around the country to join this team through their website. Importantly, Sophie decided to have a phone conversation with each new person that signed up from a new town and asked them if they would be a regional coordinator for their community. And so the SS4CNZ movement began to grow.

\section{A BRIEF NOTE ON THE WIDER CLIMATE MOVEMENT IN AOTEAROA NEW ZEALAND}

It is important to note here that SS4CNZ is a very young organization situated within a diverse and well-established wider climate movement in Aotearoa New Zealand, which has been built by many different groups and communities' over many years. SS4CNZ recognize that their work exists on the back of decades of resistance to fossil fuel development and activism by many different communities to protect the natural environment on which we depend, and which is a taonga (treasure) for our nation. SS4CNZ takes inspiration and guidance from those who have fought for climate justice before them, standing on their shoulders to play their part in mobilizing the next generation of climate activists in this eleventh hour of the fight to save our futures and our collective home.

A significant stream of the wider climate movement that exists in Aotearoa New Zealand has been the movement to end oil and gas exploration and extraction in our lands and waters. After decades of grassroots campaigning by communities, local oil-free groups, non-government organizations such as Greenpeace Aotearoa New Zealand, and Iwi and Hapu (Indigenous Māori 
tribes and sub-tribes), the newly elected coalition government announced in 2017 that they would end new offshore oil and gas exploration in Aotearoa New Zealand. ${ }^{2}$

This was a monumental win for the Aotearoa New Zealand climate movement, and a testament to the power of grassroots, people-powered movements. The newly elected Prime Minister, Jacinda Ardern, said many times on the election campaign trail that climate change was her generation's "nuclear free moment", and this politically brave step was seen by many as a strong example of this sentiment being backed by action. This win was a fresh gust of air beneath the wings of the Aotearoa New Zealand climate movement; an indication that we could win if we all came together. However, despite this step being world leading, there was still so much work to be done.

Although this announcement promised an end to new offshore oil and gas development, 57 oil and coal exploration permits remained unaffected, many of which will last for decades. Further, the government has continued to open up land onshore for fossil fuel exploration; in 2018, they opened up 2200 square kilometres of land for potential oil and gas drilling, a move that was heavily criticized by School Strikers, environmental groups and local Iwi. ${ }^{3}$ This shows that fossil fuel development is far from over in Aotearoa.

SS4C has taken on the mantle of holding the government to account on the need for bold, transformative action on a systemic level to address the climate crisis. We stand firm in the belief that no political party is currently doing enough to address this crisis. However, while many have hailed SS4C as being the "re-awakening" of youth political consciousness, we are by no means the only young people who are mobilizing on a national level in this space. Other youth activist groups, particularly Indigenous youth groups, have been actively mobilizing their communities on this issue for many years.

Two such groups are the Pacific Climate Warriors, a group of Pasifika youth who have been active in Aotearoa New Zealand for the last few years, and in the wider Pacific region for over a decade 4 and Te Ara Whatu, a group of Māori and Indigenous Pacific young people from Aotearoa who have sent Indigenous Youth Delegations to the International UN Climate Conference for the past three years. ${ }^{5}$ They are the first all-Indigenous Youth Delegation to attend these negotiations from Aotearoa. Both the Pacific Climate Warriors and Te Ara Whatu work tirelessly to bring Indigenous knowledge and understanding to spaces that are often otherwise dominated by Western scientific frameworks and worldviews. They also fight on the front lines for their communities here in Aotearoa New Zealand and the Pacific, who are not only disproportionately affected by the impacts of the climate crisis, but in their Indigenous knowledge and understanding, also hold the solutions that our world so desperately needs. For these reasons, it is fundamental that these voices are at the centre of conversations about the climate crisis and achieving climate justice. 
Drawing attention to these, and the many other environmental groups, is important in explaining the story of SS4C in Aotearoa New Zealand, because it highlights the context in which we have come to exist, and the niche we currently occupy as a movement for young Aotearoa New Zealand students to organize, mobilize and be a part of the conversation about our futures. While SS4CNZ brings a new element to the climate movement in Aotearoa New Zealand, it is important to acknowledge our allies who are in this fight alongside us.

\section{REFLECTING ON SS4CNZ'S FIRST YEAR}

On 15 February 2018, Sophie Handford was invited to speak on the TV New Zealand Breakfast Show, launching the SS4CNZ movement in national news and serving a notice to the nation that students across the country would be striking from schools, kindergartens and universities alongside the global School Strike movement on 15 March. ${ }^{6}$ Sophie was invited to bring along someone else who was involved in the movement and based in Wellington, so she invited Raven Maeder, a student at Victoria University of Wellington who had been heavily involved in getting SS4CNZ off the ground, and had been involved in mobilizing young people in the wider Aotearoa New Zealand climate movement for a number of years.

This interview propelled the movement into the national consciousness and soon more and more youth from every corner of the country were getting in contact wanting to host a strike in their town or city. By 24 February, over 15 community actions had been confirmed, with strikes in major cities such as Christchurch, Wellington, Auckland and Dunedin, some being organized by students as young as 12 years old. ${ }^{7}$ This would only increase in the following weeks.

At this time, the national response from parents, schools, media commentators, politicians and the general public was very mixed. While there was an overflowing of support from many parents, teachers and community groups who said they were inspired by young people rising up for their right to a future, and wanting to support this mobilization, there was also significant criticism and resistance. Much of the discourse in the media became centred around criticisms of the strikes taking place during school hours, rather than on the weekend. Many schools threatened to mark students as truants if they took part in the strike, with some principals saying it was just an excuse for students to skip school and their impact on climate change would be "probably zero". 8

The initial response from Members of Parliament was also very mixed. Many National Party MPs criticized the strike publicly. National MP Judith Collins was particularly dismissive, saying "Their little protest is not going to help the world one bit", and the National Party leader, Simon Bridges, 
accused the strike of being just "a couple of chants as they march along and maybe McDonald's afterwards". ${ }^{9}$ The Prime Minister, Jacinda Ardern, also had a rather unenthusiastic initial response to SS4CNZ's announcement of the first strike, telling the media: "What I'd like to think is in New Zealand there is less cause for protest. We are certainly trying to do our bit". ${ }^{10}$ However, the Minister for Climate Change and Green Party co-leader, James Shaw, came out publicly in support of SS4CNZ, saying "they have every right to fight for their future". ${ }^{11}$

While the media storm that unfolded in the lead-up to the first strike was largely dominated by argument over whether or not school students should be allowed to strike from school, or whether the protest would achieve anything, rather than the demands of the movement and the issue of the climate crisis, there was also significant support and coverage of the positive effects that the movement was already having. Further, the media attention being generated by the rigorous debate on the subject certainly fell in favour of SS4CNZ's hope to get the message about the strike out to the nation. In fact, one opinion piece argued that the school strike had been a success before it had even begun:

Arguably, it has done more to engage the community about climate change, species destruction and rising sea levels than anything else has managed to do over the past few years. Nationwide, it is igniting conversations around the dinner table about climate change - its causes and its effects - in hundreds of thousands of New Zealand homes. ${ }^{12}$

A significant success came when more than 1000 academics, teachers and researchers made the rare decision to publicly throw their support behind SS4CNZ in an open letter. ${ }^{13}$ The open letter thanked the striking students for their "leadership, and commitment to building a different world based on climate justice". ${ }^{14}$ It also spoke of the important educational opportunity that it offered for the striking students to learn "practical lessons about an issue that will confront them throughout their lifetimes, as citizens, as future scientists, and as members of the global community". ${ }^{15}$ As momentum built in the lead-up to 15 March, the discourse around the strike began to shift slightly. People began realizing that the students were serious, and they weren't going anywhere. Five days before the much-awaited date of the first strike, Raven Maeder got a text from a phone number she did not recognize while sitting on the floor of her bedroom. It was from a staffer in the Prime Minister's Office - the Prime Minister wanted to meet the strikers.

On 13 March, Prime Minister, Jacinda Ardern, and Minister for Climate Change, James Shaw, met with SS4CNZ Wellington organizers at a local high school in a "town hall"-style panel discussion attended by 130 local high school students and staff. The meeting was also live broadcast via social media, with 
questions coming from SS4CNZ organizers, the live audience and online. ${ }^{16}$ While the positive steps made by the government were acknowledged, and the Prime Minister was thanked for meeting with the strikers and recognizing the importance of listening to their concerns, the SS4CNZ representatives also grilled the Prime Minister and James Shaw, focusing squarely on the government's continuation of fossil fuel development and lack of action on emissions from the agriculture sector - which accounts for roughly 50 per cent of New Zealand's emissions profile. Sophie Handford, as one of the SS4CNZ representatives, was firm that "no political party is currently doing enough on climate change". When asked about what impact the student climate strike would have, the Prime Minister told the strikers "don't underestimate the power of your voice... I think too often we make this assessment that in order to have an impact you have to be of voting age. That is just not the case". ${ }^{17}$ She also spoke about the importance of movements like this one building more public consensus and pressure for bold action, to give government the social licence to do more.

With this wind beneath their wings, SS4CNZ organizers across the country geared up for their first strike. Sophie and Raven were invited again to speak on the TV New Zealand Breakfast Show on 15 March, the day of the first strike. ${ }^{18}$ During this interview, the pair signalled the expected turnout was anywhere between 500 and 1000 . However, on 15 March, this prediction was dwarfed by an estimated 20000 people marching in the streets of their home towns and cities. ${ }^{19}$ This turnout far exceeded what organizers up and down the country had hoped for - it was incredible and one of the largest mobilizations the country had seen in years. The mood in the crowds on the day was full of hope that the collective frustration over inaction might finally trigger real political change. The nation's youth were rising up for their futures.

Tragically, on 15 March, there was also a horrific terrorist attack targeted at two separate mosques in Christchurch, claiming the lives of 51 people in their place of worship. This date will now be remembered as one of the country's darkest days. ${ }^{20}$ SS4CNZ organizers shared in the national grief and pain of these attacks, meaning that celebration of the first strike felt not only inappropriate but impossible. Many who attended strikes across the country spoke of the sense that 15 March showed the best and worst sides of humanity, a shocking clash of opposing ideologies. In an article published in The Guardian, Rebecca Solnit wrote that climate action is the antithesis of white supremacy: "behind the urgency of climate action is the understanding that everything is connected; behind white supremacy is an ideology of separation". ${ }^{21}$

When the international FFF and SS4C movements decided for the next international strike date to be set for 24 May, SS4CNZ organizers knew they needed to mobilize again. A statement was released saying that the 15 March terror attack showed the worst side of human nature, but on 24 May students 
and the wider community would come together and share hope. As the national security threat level was still relatively high in the aftermath of 15 March, and many communities were still grieving and in pain, the decision of what kind of actions would take place on 24 May was left up to individual communities to decide locally. While some centres chose to strike and march in the streets, others organized beach clean-ups, community gatherings and tree plantings. On 24 May, the turnout was as phenomenal as the 15 March climate strike. However, the third strike, on 27 September, is the one that was truly exceptional, as a historic 170000 people went on strike for the climate.

The date of 27 September 2019 will be written into the NZ history books, with 3.5 per cent of the population uniting behind collective demands for climate justice..$^{22}$ This percentage of population turnout was the second highest per capita turnout internationally for the September school strikes, behind Tuvalu in the South Pacific, which mobilized 20 per cent of its citizens. On this day, the Pacific was leading the world on climate action! In the capital city, Wellington, school strikers and a crowd of 40000 people delivered an open letter to politicians from each major party on the steps of Parliament calling on elected leaders to do everything in their power to limit warming to $1.5^{\circ} \mathrm{C}$ and meet the five specific national demands of the movement, ${ }^{23}$ the fifth of which had been co-written by SS4CNZ and the Pacific Climate Warriors. ${ }^{24}$

Significantly, the 27 September strikes were a success because of the partnership between a range of youth climate action groups, and saw an important step towards ensuring that the voices of Indigenous youth and their communities were at the centre of the conversation around climate change. In Wellington, the strike was co-hosted by the Pacific Climate Warriors, who mobilized their communities to attend and lead the march to Parliament with traditional song and dance. In Auckland, the strike was co-hosted by SS4C Auckland, 4 Thaa Kulture - a South Auckland-based Indigenous environmentalist group of high school students - and the Pacific Climate Warriors. ${ }^{25}$ Members of Te Ara Whatu and other Indigenous youth movements were also actively involved on the day, including speeches from incredible young Indigenous leaders such as Pania Newton, the inspirational young leader who successfully led the struggle by her community to have their ancestral land, Ihumātao, returned to them in 2019, and Brianna Freuan from the Pacific Climate Warriors, who has been leading the way on climate action since she helped found 350 Sāmoa at age $11 .{ }^{26}$ Having these marches led by the communities who are on the front lines of the climate crisis was significant because it recognized that leadership needed to come from the communities who would not only be most affected by climate change, but also whose experience and knowledge is crucial in addressing the crisis. It was also fundamental to the massive turnouts, particularly in Wellington and Auckland, where the leadership of these groups meant the mass mobilization of their communities. Overall, this day saw the largest 
mass mobilization in the country's history, and in the words of the coordinator of the Wellington Pacific Climate Warriors, Mary Moeono-Kolio, it was an “intergenerational march...fighting for our Pacific people - that's what's made it for all these people to stand as one. Standing in solidarity no matter what island we come from, what we speak, just coming together"' ${ }^{27}$

In November, the Zero Carbon Bill was passed into law in Aotearoa New Zealand with near-unanimous support in Parliament. ${ }^{28}$ This was a historic moment for the nation, and the world, as the target to keep global warming within $1.5^{\circ} \mathrm{C}$ by 2050 was enshrined in law. Significantly, the blueprint of this bill, before it became adopted by the government, was written and championed by young Kiwi climate activists. The nationwide, youth-led climate organization Generation Zero began developing the Zero Carbon Bill in 2016 when they realized that if they wanted a law to put Aotearoa New Zealand on track to zero carbon by 2050, they would have to write it themselves. And so they did. ${ }^{29}$ Together with many other climate groups, business and industry allies, the scientific community and political youth wings, they campaigned for years to get the bill through Parliament with cross-partisan support. Their success truly shows the power that young people can have in affecting change at all levels.

The passing of the Zero Carbon Bill was also a significant win for SS4CNZ, as it was one of the movement's key demands of Parliament, ${ }^{30}$ and the strikes and mobilization were instrumental in building the political consensus for it to pass with cross-party support. The historic intergenerational climate strike on 27 September showed that the Aotearoa New Zealand public would not settle for inaction and were united behind the demand for an ambitious Zero Carbon Bill. However, while the bill passed was a huge success for the climate movement and heralded as "world leading", it fell short of the ambition called for by SS4CNZ, who had been pushing for the target to be pushed forward to at least 2040 to reflect Aotearoa New Zealand's ability and responsibility to lead the world in climate action and ambition. Despite pressure being applied by SS4CNZ and many other climate action groups for the government to move faster and be more ambitious, the target set out in the newly passed bill is 2050 . There were also other changes to the bill being called for by SS4CNZ, such as stronger targets for greenhouse gas emissions and for legal enforceability measures to be put in place for the targets; however, these were not included in the final bill. However, overall, the passing of this bill is world leading and a great win for the climate movement in Aotearoa and the world. It sends a strong signal to all societal and economic sectors in New Zealand of the direction in which we are heading as a nation, and that everyone must play their role in moving towards a zero-carbon future.

Reflecting on SS4CNZ's first year, there are many other wins to recount. A significant one has been the increasing support from the government for the strikes, reflected clearly in the Ministry of Education's change of tone 
towards the strikes ${ }^{31}$ and the government's recent announcement that a new climate change education resource will be in schools in 2020. ${ }^{32}$ Further, the widespread support from all sectors of Aotearoa New Zealand society has been immense. Over 290 businesses and their staff signed up to support and mobilize during the strike on 27 September $^{33}$ and all but one of the major Aotearoa New Zealand universities and tertiary institutions endorsed and took part in 27 September. ${ }^{34}$ Unions also supported the September strike, not only through spreading the word through their membership bases, but also financially and logistically. Further, only several months ago, SS4CNZ was named as one of the most powerful groups fighting for climate justice in Aotearoa New Zealand. ${ }^{35}$ Members of the movement have been recognized for their work and contributions through a range of national and local awards, including the NZ Youth Award, an Impact Award, a Girlboss NZ Award and Wellingtonian of the Year. Most significantly, the major success of the movement in its first year has been the partnerships that it has formed with groups such as the Pacific Climate Warriors, Te Ara Whatu and 4 Thaa Kulture, without whom these many successes would not have been achieved.

There has also been significant learning, and there is much more work to do to ensure that this movement is successful, and upholds the values, stories and understandings that are needed to fix this crisis. The importance of having full inclusion of Māori and Pasifika rangatahi (youth), as well as ensuring the voices of marginalized youth are meaningfully included and empowered in the conversation, has become incredibly clear. With the movement having grown so rapidly, time was of the essence and group structure was lacking. This has meant that issues such as structural racism and negative power dynamics that exist in our society have not successfully been addressed within the movement, meaning that it is currently not a space in which all young Aotearoa New Zealanders feel able to participate and be fully included. Ensuring this is addressed is key to the movement's success and there is still much more work to be done.

Moving forward, SS4CNZ organizers say they have much to learn from older activists, and other youth climate groups who have created structures for movements before and will be continuing to learn to take leadership from decades of resistance that have gone before them. There is a real need for intergenerational solidarity for exchange of learnings, ideas and perspectives and because we are stronger and more resilient together. Further, it is clear that creating space for and upholding Indigenous leadership is key to ensuring that the root causes of the climate crisis are addressed, and that we collectively work towards a future that upholds justice for people and planet, rather than perpetuate existing injustices and the systems that have brought us to the point of ecological and social crisis. 
The movement is continuing to grow in Aotearoa New Zealand, with support from older generations, and a political awakening in young people is rippling across the nation. Young people are realizing the importance of having their voice heard at this moment in history to protect and safeguard this planet for generations to come and advocate for the planet that has no voice of its own. This is becoming a catalyst for the creation of a social climate where young people are infiltrating positions of power. In the most recent local council elections, where around 70 youth under the age of 30 ran for a seat at the council table, ${ }^{36}$ a number of young candidates, including SS4CNZ's own Sophie Handford, were elected to represent their communities in local government. ${ }^{37}$ Running to be an elected member is only one way in which youth from Aotearoa New Zealand have been making their voice heard. There are so many young people taking action in a variety of different ways such as through art, song writing, non-violent direct action, speech and storytelling. Each month, more and more young people are joining the movement, bringing new skills, perspectives and ideas to the team.

The year 2019 was only the beginning of the SS4C movement in Aotearoa New Zealand and the mobilization we have achieved is showing no signs of slowing down. We will not stop until all our demands of our government are met, and leaders internationally act now to address climate change as the crisis that it is. We will continue to stand for our right to a safe, liveable future on this one planet we all call home. This is only the beginning.

\section{NOTES}

1. SS4CNZ (n.d.), "The School Strike 4 Climate NZ demands", accessed 13 November 2019 at https://docs.google.com/document/d/1Vb4voJUHwmPv ul75AHIBw7QoIo6oaviCI8U9 HTYIzhs/edit.

2. Hannah Rutherford and Laura Waters (2018), "Government aims to strike balance ending offshore oil exploration: PM”, Stuff.co.nz, 12 April, 13 November 2019 at https://www.stuff.co.nz/business/103031705/ardern-to-end-to-offshore-oil -exploration-with-shortreprieve-for-taranaki? $\mathrm{rm}=\mathrm{m}$.

3. New Zealand Herald (2019), "Government offers Taranaki land to oil explorers in block offer but with tight new restrictions, including near top surf breaks", 30 April, 21 November 2019 at https://www.nzherald.co.nz/business/news/article .cfm?c id=3\&objectid=12226614.

4. 350 Pacific (n.d.), "Pacific Climate Warriors", 21 November 2019 at https:// 350pacific.org/pacific-climate-warriors/.

5. Te Ara Whatu (n.d.), [website] 21 November 2019 at https://tearawhatu.org/.

6. Facebook.com (2019), "New Zealand has just been served notice", 15 February, 1 December 2019 at https://www.facebook.com/watch/?v=318382278670482.

7. SS4CNZ (2019), "Everyday, new towns are getting on board and choosing to strike for urgent climate action on March 15th! Send us a message if you're organising something in your community", Facebook.com, 24 February, 1 December 2019 at 
https://www.facebook.com/schoolstrike4climatenz/photos/a.287831771883948/ 291224078211384/?type $=3 \&$ theater.

8. Amber-Leigh Woolf and Adele Redmond (2019), "Students who strike for climate change will be marked as truants, principals say", Stuff.co.nz, 7 March, accessed 11 January 2020 at https://www.stuff.co.nz/environment/climate-news/ 111013724/students-who-strike-for-climate-change-will-be-marked-as-truants -principals-say.

9. Dan Satherley (2019), "Simon Bridges questions whether ends justify the means in climate protest", Newshub.co.nz, 11 March, accessed 11 January 2020 at https:// www.newshub.co.nz/home/politics/2019/03/simon-bridges-questions-whether -ends-justify-the-means-in-climate-protest.html.

10. Ibid.

11. 1 News (2019), "Minister supports student strike against climate change inaction during school time", 4 March, accessed 11 January 2020 at https://www.tvnz .co.nz/one-news/new-zealand/minister-supports-student-strike-against-climate -change-inaction-during-school-time.

12. Gordon Campbell (2019), "Gordon Campbell on the school climate strike", Scoop. co.nz, 14 March, accessed 11 January 2020 at https://www.scoop.co.nz/stories/ HL1903/S00081/gordon-campbell-on-the-school-climatestrike.htm.

13. RNZ (2019), "Academics, teachers back students' climate strike", 9 March, accessed 11 January 2020 at https://www.rnz.co.nz/news/national/384350/ academics-teachers-back-students-climate-strike.

14. Ibid.

15. Ibid.

16. Lee Kenny (2019), "Prime Minister Jacinda Ardern met with student climate change protesters in Wellington", Stuff.co.nz, 13 March, accessed 20 January 2020 at https://www.stuff.co.nz/environment/climate-news/111237038/prime-minister -jacinda-ardern-meets-student-climate-change-protesters-in-wellington.

17. Zane Small (2019), "Student asks Jacinda Ardern what difference School Strike 4 Climate will make", Newshub.co.nz, 13 March, accessed 20 January 2020 at https://www.newshub.co.nz/home/politics/2019/03/student-asks-jacinda-ardern -what-difference-school-strike-4-climate-will-make.html.

18. 1 News (2019), “'It is the nuclear-free issue of our generation' - student protest organisers discuss striking for climate change", 15 March, accessed 20 January 2020 at https://www.tvnz.co.nz/one-news/new-zealand/-nuclear-free-issue-our -generation-student-protest-organisers-discuss-striking-climate-change.

19. Ibid.

20. Kate Newton et al. (2019), "New Zealand's darkest day", RNZ.co.nz, 15 March, accessed 26 January 2020 at https://shorthand.radionz.co.nz/NZ-DARKEST -DAY/index.html.

21. Rebecca Solnit (2019), "Why climate action is the antithesis of white supremacy", The Guardian, 19 March accessed 26 January 2020 at https://www.theguardian .com/commentisfree/2019/mar/19/why-youll-never-meet-a-white-supremacist -who-cares-about-climate-change.

22. RNZ (2019), "Thousands - young and old - demand government action on climate change", 27 September, accessed 26 January 2020 at https://www.rnz.co.nz/ news/national/399778/thousands-young-and-old-demand-government-action-on -climate-change.

23. Eleanor Ainge Roy (2019), “'Nothing else matters': school climate strikes sweep New Zealand”, The Guardian, 27 September, accessed 28 January 2020 at https:// 
www.theguardian.com/environment/2019/sep/27/nothing-else-matters-school -climate-strikes-sweep-new-zealand.

24. Georgia Forrester (2019), "Student climate change stroke: why young Kiwis are demanding more action", Stuff.co.nz, 27 September, accessed 28 January 2020 at https://www.stuff.co.nz/environment/climate-news/115713822/student-climate -change-strike-why-young-kiwis-are-demanding-more-action.

25. Jamie Tahana (2019), “'We're not drowning, we're fighting': Pacific youth lead climate march”, RNZ.co.nz, 27 September, accessed 28 January 2020 at https:// www.rnz.co.nz/international/pacific-news/399785/we-re-not-drowning-we-re -fighting-pacific-youth-lead-climate-march.

26. Josephine Franks (2019), "Climate change strike: up to 80000 protesters form human chain in Auckland", Stuff.co.nz, 27 September, accessed 28 January 2020 at https://www.stuff.co.nz/environment/climate-news/116143489/climate-change -strike-up- to-80000-protesters-form-human-chain-in-auckland.

27. Jamie Tahana (2019), in note 25.

28. Henry Cooke (2019), "Zero Carbon Bill passes with near-unanimous support, setting climate change targets into law", Stuff.co.nz, 7 November, accessed 28 January 2020 at https://www.stuff.co.nz/national/politics/117244331/national -will-support-climate-change-zero-carbon-bill.

29. Generation Zero (2020), "Our story", accessed 26 August 2020 at https://www .generationzero.org/our_story.

30. SS4CNZ (n.d.), "The School Strike 4 Climate NZ demands", in note 1.

31. Ministry of Education (2019), "Attendance and the School Strike 4 Climate", accessed 28 January 2020 at https://www.education.govt.nz/news/attendance-and -the-school-strike-4-climate-change.

32. Stuff (2020), "Climate change education resource to be in schools in 2020", 12 January, accessed 28 January 2020 at https://www.stuff.co.nz/environment/climate -news/118703882/climate-change-education-resour ce-to-be-in-schools-in-2020.

33. Debrin Foxcroft (2019), "New Zealand companies join students in support for the global climate strike", Stuff.co.nz, accessed 31 January 2020 at https://www.stuff .co.nz/business/116139687/new-zealand-companies-join-students-in-support-for -the-global-climate-strike; Spreaker (2020), "Lucy Kebbell: businesses join children to march against climate change" [podcast], 31 January 2020 at https://www .spreaker.com/user/nzme/lucy-kebbell-businesses-join-children-to; Not Business as Usual (n.d.), "This is not business as usual", 31 January 2020 at https://www .notbusinessasusual.co/.

34. Josephine Franks (2019), "Climate change strike: Auckland Uni the only NZ university not to back action", Stuff.co.nz, 18 September, 31 January 2020 at https:// www.stuff.co.nz/environment/climate-news/115871974/climate-change-strike -auckland-uni-the-only-nz-university-not-to-back-action.

35. Andrea Vance, Charlie Mitchell and Henry Cooke (2019), "New Zealand's climate change power list", Stuff.co.nz, 16 September, accessed 5 February 2020 at https://www.stuff.co.nz/environment/climate-news/115727267/new-zealands -climate-change-power-list.

36. Peter MacKenzie (2019), "Echoing Chloe Swarbrick, a 'youthquake' rumbles through Wellington's political scene", The Spinoff, 7 June, accessed 5 February 2020 at https://thespinoff.co.nz/politics/07-06-2019/echoing-chloe-swarbrick-a -youthquake-rumbles-thro ugh-wellingtons-political-scene/.

37. Charlotte Graham-McLay (2010), “'Youthquake': the young New Zealanders voted into office - in between McDonald's shifts", The Guardian, 17 October, 
accessed 5 February 2020 at https://www.theguardian.com/world/2019/oct/17/ youthquake-the-young-new-zealanders-voted-i nto-office-in-between-mcdonald s-shifts. 